\title{
Pemetaan Kompetensi Pedagogik, Profesional, Kepribadian dan Sosial Guru Fisika SMA di Kabupaten Kulon Progo Pascasertifikasi
}

\author{
Boy Diokta Cahyotlogo ${ }^{1}$, Jumadi $^{2}$ \\ ${ }^{1,2)}$ Program Pascasarjana, Universitas Negeri Yogyakarta \\ Email: boy.armory@yahoo.com ${ }^{1}$; jumadi @uny.ac.id ${ }^{2}$
}

Received April 27, 2017; Revised August 26, 2017; Accepted September 29, 2017

\begin{abstract}
Abstrak
Tujuan penelitian ini untuk mendapatkan gambaran peta kompetensi guru fisika SMA di Kabupaten Kulon Progo dari aspek kompetensi pedagogik, profesional, kepribadian, dan sosial. Jenis penelitian ini adalah penelitian deskriptif evaluatif. Penelitian ini dilaksanakan di tiga belas (13) SMA Negeri dan Swasta di Kabupaten Kulon Progo. Subjek penelitian ini adalah guru fisika SMA yang sudah memiliki sertifikat pendidik berjumlah 23 guru. Sampel penelitian dipilih dengan menggunakan teknik sampling jenuh. Pengumpulan data penelitian diperoleh melalui lembar angket, observasi, analisis dokumen, dan portofolio guru fisika yang bersangkutan. Hasil penelitian ini menunjukkan bahwa: (1) penguasaan kompetensi pedagogik guru fisika yang sudah sertifikasi secara keseluruhan masuk dalam kategori baik, (2) penguasaan kompetensi profesional guru fisika yang sudah sertifikasi pada aspek menguasai substansi keilmuan yang terkait dengan bidang studi yang diampu masuk dalam kategori baik dan pada aspek menguasai struktur dan metode keilmuan masuk dalam kategori cukup, (3) penguasaan kompetensi kepribadian guru fisika yang sudah sertifikasi secara keseluruhan masuk dalam kategori sangat baik, dan (4) penguasaan kompetensi sosial guru fisika yang sudah sertifikasi secara keseluruhan masuk dalam kategori baik.
\end{abstract}

Kata kunci: Peta kompetensi guru, pedagogik, profesional, kepribadian, sosial

\section{The Mapping of Pedagogic, Professional, Personal, and Social Competencies of Certified Physics Teachers In Senior High Schools In Kulon Progo Regency}

\begin{abstract}
This study aims to map the competencies of certified physics teachers in senior high schools (SHSs) in Kulon Progo Regency in terms of the aspects of pedagogic, professional, personal, and social competencies. This was a description evaluative study. It was conducted in 13 state and public SHSs in Kulon Progo Regency. The research subjects were SHSs physics teachers having obtained educator certificates with a total of 23 teachers. The research sample was selected by means of the saturated sampling technique. The assessment was conducted by principals, peer teachers, students, and physics teachers. The data were collected through a questionnaire, observations, document analysis, and physics teachers' portfolios. The results of the study show that on the whole: (1) the certified physics teachers' pedagogic competency is good, (2) their professional competency in the aspect of the mastery of the subject matter substance related to the field of study is good and that in the aspect of the mastery of the scientific structure and method is moderate, (3) their personal competency is very good, and (4) their social competency is good.
\end{abstract}

Keywords: Teacher competency map, pedagogical, professional, personality competence, social

DOI : 10.25273/jpfk.v3i2.1199

\section{Pendahuluan}

Undang-Undang Republik Indonesia nomor 20 tahun 2003, tentang Sistem Pendidikan Nasional pada bab 1 pasal (1) menyatakan bahwa pendidikan adalah usaha sadar dan terencana untuk mewujudkan suasana belajar dan proses pembelajaran agar peserta didik secara aktif mengembangkan potensi dirinya untuk memiliki kekuatan spiritual keagamaan, pengendalian diri, 
kepribadian, kecerdasan, akhlak mulia, serta keterampilan yang diperlukan dirinya, masyarakat, bangsa, dan negara (Depdiknas, 2003). Berdasarkan isi Undang-Undang tersebut, maka pendidikan merupakan suatu wahana yang diarahkan untuk meningkatkan kualitas sumber daya manusia agar dapat memenuhi kebutuhan pembangunan bangsa Indonesia. Selain itu pendidikan merupakan proses transformasi budaya, proses pembentukan karakter, dan proses pengembangan life skill masyarakat Indonesia.

Mutu pendidikan dipengaruhi oleh berbagai macam faktor diantaranya adalah sistem pendidikan, manajemen pendidikan, kurikulum, anggaran pendidikan, sarana dan prasarana serta profesionalisme pendidik atau guru. Prestasi dan kualitas lulusan (outcome) merupakan tolok ukur dari mutu pendidikan di Indonesia.

Pada tahun 2009 Programme for International Assessment (PISA) mengadakan studi internasional tentang kemampuan literasi, matematika dan sains siswa sekolah lanjutan tingkat pertama. Berdasarkan data hasil survei PISA bahwa rata-rata skor prestasi siswa di Indonesia berada signifikan di bawah rata-rata skor internasional. Prestasi literasi Indonesia berada di peringkat 57 dari 65 negara dengan rata-rata skor 402 dan rata-rata skor internasional 493. Prestasi matematika Indonesia berada di peringkat 61 dari 65

Guru merupakan agen pembelajaran yang mendukung keterlaksanaan proses pembelajaran di kelas. Guru adalah pendidik profesional dengan tugas utama mendidik, mengajar, membimbing, mengarahkan, menilai, dan mengevaluasi peserta didik pada pendidikan anak usia dini, jalur pendidikan formal, pendidikan dasar, dan pendidikan menengah (Depdiknas, 2005). Undang-Undang nomor 14 tahun 2005, mensyaratkan bahwa seorang guru harus memiliki kualifikasi akademik minimum sarjana (S-1) atau diploma empat (D-4), menguasai empat kompetensi meliputi kompetensi pedagogik, profesional, kepribadian dan sosial, memiliki sertifikat pendidik, sehat jasmani dan rohani serta memiliki kemampuan untuk mewujudkan tujuan pendidikan nasional (Depdiknas, 2005). Lynn dan Nixon (1985, p.33) menjelaskan Dalam Undang-Undang nomor 20 tahun 2003 Bab XI pasal 40 ayat 2, dijelaskan bahwa negara dengan rata-rata skor 372 dan rata-rata skor internasional 496, dan prestasi sains berada di peringkat 60 dari 65 negara dengan rata-rata skor 383 dan rata-rata skor internasional 501 (OECD, 2010). Hasil tersebut secara umum mengindikasikan masih rendahnya mutu pendidikan di Indonesia. Salah satu aspek yang diduga sebagai penyebab rendahnya mutu pendidikan di Indonesia adalah kualitas guru yang diukur melalui profesionalisme guru. Kondisi ini sangat ironis mengingat berbagai upaya yang telah dilakukan pemerintah dalam meningkatkan mutu, kualitas dan kesejahteraan guru.

Pada tahun ajaran 2011/2012 di Provinsi Daerah Istimewa Yogyakarta (DIY) dan khususnya di Kabupaten Kulon Progo terdapat permasalahan berkaitan dengan pencapaian hasil belajar fisika yang terukur melalui perolehan nilai Ujian Nasional (UN). Berdasarkan data yang diperoleh dari Disdikpora Provinsi Daerah Istimewa Yogyakarta (DIY) terungkap bahwa hasil rerata skor Ujian Nasional (UN) Fisika tingkat SMA/MA pada tahun ajaran 2011/2012 di Provinsi DIY sebesar 5,08 dan khususnya di Kulon Progo sebesar 4,88. Hasil tersebut menunjukkan rendahnya rerata skor UN Fisika baik di tingkat Provinsi DIY maupun di Kabupaten Kulon Progo.

"competencies may range from recall and understanding of facts and copcepts, to advanced motor skill, to teaching behaviors, and professional values". Kompetensi terdiri dari pengalaman dan pemahaman tentang fakta dan konsep, peningkatkan keahlian, pengajaran perilaku dan sikap. Brooke dan Stone (Mulyasa, 2013, p.62) berpendapat bahwa kompetensi sebagai "descriptive of qualitative nature of teacher behavior appears to be entirely meaningful", artinya kompetensi merupakan gambaran hakikat kualitatif dari perilaku guru atau tenaga kependidikan yang yang tampak sangat berarti. Dengan demikian, kompetensi merupakan perpaduan dari pengetahuan, keterampilan, nilai dan sikap yang direfleksikan dalam kebiasaan berpikir dan bertindak

pendidik dan tenaga kependidikan berkewajiban menciptakan suasana pendidikan 
yang bermakna, menyenangkan, kreatif, dinamis dan dialogis; mempunyai komitmen secara profesional untuk meningkatkan mutu pendidikan dan memberi teladan; serta menjaga nama baik lembaga, profesi, dan kedudukan sesuai dengan kepercayaan yang diberikan kepadanya (Depdiknas, 2003).

Guru adalah orang yang berpengetahuan luas (well-informed), oleh karena itu guru senantiasa memperbaharui wawasan dan pemahamannya dengan membaca buku-buku dan jurnal-jurnal ilmiah kependidikan, terlibat dalam berbagai kegiatan profesional dan peduli untuk memajukan pengembangan profesionalnya melalui tugas-tugas dalam jabatan (Payong, 2011, p.4). Guru adalah orang dewasa yang secara sadar dan bertanggung jawab dalam mendidik, mengajar, dan membimbing peserta didik (Uno, 2007, p.15). Berdasarkan pendapat tersebut bahwa guru adalah orang memiliki kemampuan merancang program pembelajaran, serta mampu menata dan mengelola kelas agar siswa dapat belajar dan pada akhirnya dapat mencapai tingkat kedewasaan sebagai tujuan akhir dari proses pendidikan.

Landasan posisi strategis pendidik atau guru dijabarkan dalam Undang-Undang Republik Indonesia nomor 14 tahun 2005 tentang Guru dan Dosen. Undang-Undang tersebut menyatakan bahwa kedudukan guru sebagai tenaga profesional berfungsi untuk meningkatkan martabat guru serta perannya sebagai agen pembelajaran dalam meningkatkan mutu pendidikan nasional (Depdiknas, 2005). Secara eksplisit amanat Undang-Undang tersebut adalah berkaitan dengan kebijakan pembinaan dan pengembangan profesi guru agar memiliki seperangkat pengetahuan, keterampilan dan perilaku yang diaktualisasikan untuk menjalankan profesi mendidik.

Guru sebagai tenaga profesional mengandung arti bahwa pekerjaan guru hanya dapat dilakukan oleh seseorang yang memiliki kompetensi tertentu, yaitu kompetensi pedagogik, kepribadian, sosial, dan profesional. Dalam hal ini profesional adalah pekerjaan atau kegiatan yang dilakukan oleh seseorang dan menjadi sumber penghasilan kehidupan yang memerlukan keahlian, kemahiran atau kecakapan yang memenuhi standar mutu atau norma tertentu serta memerlukan pendidikan profesi (Wahab, 2011, p.1). Sebagai tenaga profesional, guru dituntut untuk selalu mengembangkan diri dalam mengakses perubahan metode pembelajaran maupun kemajuan ilmu pengetahuan dan teknologi. Kualifikasi dan kompetensi seorang guru menjadi syarat penting untuk menunjukkan bahwa pekerjaan profesional yang memiliki dasar keilmuan dan teori tertentu.

Penilaian dan sertifikasi kompetensi guru untuk pengembangan karir dalam jabatan meliputi beberapa hal diantaranya: (a) kompetensi kemampuan bidang studi; (b) kompetensi pemahaman karakteristik peserta didik; (c) kompetensi pembelajaran yang mendidik; (d) kompetensi pengembangan profesi dan kompetensi kepribadian pendidik. Mastiyah (2004, p.2) berpendapat bahwa dewasa ini kompetensi guru baik kompetensi pedagogik, profesional, kepribadian maupun sosial masih belum memadai. Hal ini dapat dilihat dari kurangnya kematangan emosional dan kemandirian berpikir, lemahnya motivasi dan dedikasi serta lemahnya penguasaan bahan ajar dan cara pengajaran yang kurang efektif.

Untuk meningkatkan mutu pendidikan pada jenjang pendidikan menengah yaitu SMA/MA, maka perlu dilakukan usaha yang sadar dalam meningkatkan mutu penyelenggaraan pendidikan SMA/MA yang salah satu indikatornya adalah mutu guru yang dapat terukur melalui kompetensi. Dalam upaya meningkatkan kompetensi guru, maka harus dipahami apa dan bagaimana karakteristik kerja guru. Sejalan dengan karakteristik tersebut, maka pengembangan jenjang promosi karier guru harus senantiasa bertumpu pada hakekat kerja guru. Guru bertugas untuk mengajar dan melangsungkan proses pembelajaran. Pembinaan kualitas profesional guru yang terkandung dalam kebijakan jenjang jabatan fungsional, bertumpu pada kemampuan melaksanakan pembelajaran tersebut.

Seorang guru wajib memiliki kemampuan pengetahuan sesuai dengan bidang ilmu yang diampunya yang lebih mendalam dan mendasar melebihi muatan pembelajaran yang dibebankan kepada peserta didik. Di dalam proses pembelajaran khususnya mata pelajaran fisika, maka seorang guru fisika harus dapat melakukan proses 
pembelajaran secara efisien, efektif dan terpadu serta dapat merencanakan dan melaksanakan pembelajaran fisika yang kondusif. Selain itu, guru fisika harus mampu memberikan pemahaman tentang aplikasi konsep Fisika dalam kehidupan sehari-hari untuk penyelesaian masalah-masalah yang bersifat konkret.

Fisika merupakan bagian dari ilmu pengetahuan yang didasarkan pada hasil pengamatan atau observasi. Berdasarkan itu, kebenaran dalam fisika dengan sendirinya bersifat relatif dan progresif sesuai dengan kemampuan dan teknik pengamatan atau pengukuran yang berkembang dalam proses penyempurnaan secara terus-menerus. Fisika sebagai bagian dari sains pada hakekatnya merupakan proses ilmiah, produk ilmiah, dan sikap ilmiah. Carin dan Sund (1989, p.2) menjelaskan bahwa sains memiliki tiga elemen utama, yaitu scientific attitudes, scientific process, and scientific product.

Fisika merupakan mata pelajaran dasar yang membicarakan tentang fenomena alam disekitar lingkungan, sehingga peran guru sangat penting dalam mengarahkan siswa untuk menguasai konsep agar dapat menyelesaikan masalah konkret dalam kehidupan sehari-hari. Seorang guru fisika dituntut harus kompeten dan profesional untuk melayani peserta didik dalam proses pembelajaran. Proses pembelajaran Fisika di sekolah yang sering mengalami banyak hambatan, tantangan serta tuntutan pada jenjang SMA, diharapkan mampu menghasilkan lulusan yang memiliki kompetensi. Oleh karena itu, sistem

Tabel 1. Hasil perolehan skor UKG Fisika SMA di Kulon Progo tahun 2012

\begin{tabular}{ccccc}
\hline No. & Kode Peserta & Skor Benar & Skor Salah \\
\hline 1 & Tmn-1 & 48,75 & 51,25 \\
\hline 2 & Tmn-2 & 47,5 & 52,5 \\
\hline \hline 4 & Peng-1 & 37,5 & 62,5 \\
\hline 5 & Peng-2 & 46,25 & 53,75 \\
\hline 6 & Ma'arif-1 & 37,5 & 62,5 \\
\hline 7 & Ma'arif-2 & 48,75 & 51,25 \\
\hline 8 & Muh-1 & 38 & 62 \\
\hline 9 & $1-W t s-1$ & 26 & 74 \\
\hline 10 & $1-W t s-2$ & 41,25 & 58,75 \\
\hline 11 & $1-W t s-3$ & 48 & 52 \\
\hline 12 & $1-W t s-4$ & 59 & 41 \\
\hline 13 & $2-W t s-1$ & 58,75 & 41,25 \\
\hline
\end{tabular}

pembelajaran fisika di SMA memerlukan strategi, metode dan target yang harus dimiliki oleh guru fisika atau kompetensi guru yang mumpuni serta mampu menghasilkan peserta didik yang memiliki kompetensi standar yang diharapkan.

Guru sebagai pelaksana kurikulum perlu dipersiapkan dengan baik agar mampu menjabarkan kurikulum dengan tepat sehingga menghasilkan pembelajaran yang bermutu. Pelatihan dan penataran yang dilakukan oleh pemerintah maupun dalam wadah MGMP ditujukan agar guru mampu berpikir dan bertindak secara komprehensif, yaitu mulai dari memahami, mengerti dan selanjutnya mengimplementasikan di dalam proses pembelajaran.

Tingkat kualitas guru khususnya guru bidang studi fisika di berbagai daerah sangat beragam. Guru fisika berkualitas dengan kualifikasi pendidikan yang tinggi, sarana dan prasarana yang lengkap terdapat di beberapa daerah, namun di sebagian besar daerah lain kualitas guru fisika masih dibawah standar, bahkan masih kekurangan tenaga guru fisika serta sarana dan prasarana yang tidak memadai, bahkan tidak ada sama sekali. Kondisi di lapangan berkaitan dengan kualitas guru fisika khususnya pada jenjang SMA di Kabupaten Kulon Progo dapat dilihat dari hasil Uji Kompetensi Guru yang telah dilaksanakan.

Uji Kompetensi Guru (UKG) Fisika SMA pada tahun 2012 di Kabupaten Kulon Progo diikuti oleh 23 orang peserta. Data hasil Uji Kompetensi Guru (UKG) tersebut ditunjukkan pada Tabel 1. 


\begin{tabular}{cccc}
\hline 14 & 2 -Wts-3 & 67,5 & 32,5 \\
\hline 15 & Lndh-1 & 41,25 & 58,75 \\
\hline 16 & Lndh-2 & 42,5 & 57,5 \\
\hline 17 & Galur-1 & 48,75 & 51,25 \\
\hline 18 & Giri-1 & 61,25 & 38,75 \\
\hline 19 & Kali-1 & 37 & 63 \\
\hline 20 & Kokap-1 & 28,75 & 71,25 \\
\hline 21 & Sami-1 & 52,5 & 47,5 \\
\hline 22 & Sntlo-1 & 66,25 & 33,75 \\
\hline 23 & Sntlo-2 & 52 & 48 \\
\hline & & (LPMP DIY $: 2012)$
\end{tabular}

Berdasarkan data yang diperoleh dari Lembaga Penjaminan Mutu Pendidikan (LPMP) Provinsi DIY, dapat diketahui bahwa hasil Uji Kompetensi Guru fisika SMA Negeri dan Swasta di Kabupaten Kulon Progo mencapai skor tertinggi 67,5 dan skor terendah 26, dengan rerata skor sebesar 48,1 . Berdasarkan hasil tersebut maka seluruh guru fisika SMA Negeri dan Swasta yang mengikuti UKG tidak mencapai skor 70 yang digunakan sebagai skor minimal kelulusan UKG. Dari hasil ini mengindikasikan bahwa guru fisika SMA di Kabupaten Kulon Progo belum memenuhi kompetensi wajib yang dipersyaratkan. Pelaksanaan uji kompetensi guru yang dilakukan pada tahun 2012 untuk mengukur kompetensi pedagogik dan kompetensi profesional, melalui tes atau penilaian dengan sistem online dan berbasis komputer.

Dari paparan yang telah diuraikan di atas, maka untuk mengetahui tingkat penguasaan kompetensi guru fisika secara utuh dan sesuai dengan mekanisme perlu dilakukan suatu penelitian yang dapat memberikan gambaran peta kompetensi guru fisika SMA di Kabupaten Kulon Progo. Kompetensi guru fisika yang akan diukur pada penelitian ini mencakup empat kompetensi, yaitu kompetensi pedagogik, profesional, kepribadian dan sosial. Hasil penelitian ini dapat digunakan sebagai dasar pertimbangan dalam pemberian program pembinaan dan pengembangan profesi guru khususnya guru

Tabel 2. Data skor dan akreditasi SMA di Kabupaten Kulon Progo

\begin{tabular}{clcc}
\hline No. & \multicolumn{1}{c}{ Nama SMA } & Skor & Akreditasi \\
\hline 1. & SMAN 2 Wates & 95,31 & A \\
2. & SMAN 1 Wates & 95,30 & A \\
3. & SMAN 1 Temon & 91,36 & A \\
4. & SMAN 1 Galur & 86,14 & A \\
5. & SMAN 1 Pengasih & 94,15 & A \\
6. & SMAN 1 Sentolo & 93,01 & A
\end{tabular}




$\begin{array}{clcc}\text { 7. } & \text { SMAN 1 Kokap } & 86,84 & \text { A } \\ \text { 8. } & \text { SMAN 1 Kalibawang } & 92,03 & \text { A } \\ \text { 9. } & \text { SMAN 1 Lendah } & 93,18 & \text { A } \\ \text { 10. } & \text { SMAN 1 Samigaluh } & 90,13 & \text { A } \\ \text { 11. } & \text { SMAN 1 Girimulyo } & 94,54 & \text { A } \\ \text { 12. } & \text { SMA Ma'arif Wates } & 82,74 & \text { B } \\ \text { 13. } & \text { SMA Muhammadiyah Wates } & 78,93 & \text { B }\end{array}$

(BAP-S/M DIY: 2012)

Subjek penelitian ini adalah guru fisika pada satuan pendidikan SMA negeri dan swasta yang berada di wilayah Dinas Pendidikan Kabupaten Kulon Progo. Objek penelitian ini adalah kompetensi pedagogik,kompetensi profesional, kompetensi kepribadian dan kompetensi sosial guru fisika.

Populasi penelitian adalah guru fisika SMA negeri dan swasta yang berunit kerja di Kabupaten Kulon Progo. Guru fisika SMA sebagai populasi penelitian tersebar di beberapa SMA di Kabupaten Kulon Progo pada dua belas (12) wilayah kecamatan yang cukup luas

Sampel penelitian diambil menggunakan teknik sampling jenuh yaitu teknik pengambilan sampel dengan semua anggota populasi diambil sebagai sampel. Teknik sampling tersebut dilakukan karena jumlah populasi relatif kecil, yaitu kurang dari 30 orang. Guru yang terpilih sebagai sampel penelitian berjumlah 23 orang guru fisika.
Pengumpulan data dilakukan dengan teknik non tes.

Validitas instrumen yang digunakan adalah validitas isi. Untuk melakukan uji validitas isi atau konten dilakukan dengan cara menyusun kisi-kisi instrumen yang dikembangkan dari kajian teori. Setelah rancangan instrumen disusun kemudian dilakukan judgement oleh dua orang ahli. Dengan cara tersebut diharapkan butir-butir pernyataan pada instrumen telah mencakup semua isi dari objek yang akan diukur.

Pengujian reliabilitas instrumen dilakukan dengan cara mencobakan instrumen sekali saja, kemudian hasil yang diperoleh dianalisis dengan teknik Alpha Cronbach menggunakan software SPSS 16. Dari analisis tersebut diperoleh koefisien Alpha Cronbach. Rekapitulasi data hasil uji reliabilitas untuk masing-masing instrumen penelitian kompetensi pedagogik, profesional, kepribadian, dan sosial disajikan pada Tabel 3.

Tabel 3. Hasil uji reliabilitas instrumen

\begin{tabular}{cll}
\hline \multirow{2}{*}{ Instrumen } & \multicolumn{1}{c}{ Penilai } & $\begin{array}{c}\text { Nilai } \alpha \\
\text { Cronbach }\end{array}$ \\
\hline \multirow{3}{*}{ Pedagogik } & Kepala Sekolah & 0,813 \\
\cline { 2 - 3 } & Rekan sejawat & 0,932 \\
\cline { 2 - 3 } & Siswa & 0,931 \\
\hline \multirow{2}{*}{ Profesional } & Kepala Sekolah & 0,860 \\
\cline { 2 - 3 } & Rekan sejawat & 0,910 \\
\hline \multirow{3}{*}{ Sosial } & Kepala Sekolah & 0,895 \\
\cline { 2 - 3 } & Rekan sejawat & 0,955 \\
\cline { 2 - 3 } Kepribadian & Siswa & 0,921 \\
\cline { 2 - 3 } & Kepala sekolah & 0,878 \\
\cline { 2 - 3 } & Rekan sejawat & 0,933 \\
\hline \multirow{2}{*}{ Siswa } & 0,829 \\
\hline
\end{tabular}

Dalam penelitian ini pengumpulan data dilakukan dengan teknik non tes. Teknik non tes untuk mengumpulkan data dilakukan dengan pengamatan sistematis (observasi), angket (kuesioner), dan pemeriksaan dokumen (analisis dokumen). Teknik pengumpulan data dalam penelitian ini digunakan untuk menggali dan mengetahui kompetensi pedagogik, profesional, kepribadian dan sosial guru fisika.

Instrumen penelitian yang digunakan untuk menggali informasi mengenai kompetensi pedagogik, profesional, kepribadian, dan sosial merupakan pengembangan dari Permendiknas nomor 16 tahun 2007 tentang Standar Kualifikasi 
Akademik dan Kompetensi Guru. Instrumen pengumpulan data tersebut menggunakan lembar angket, lembar observasi, dan lembar analisis dokumen. Jenis angket yang digunakan dalam penelitian ini adalah angket tertutup. Angket yang digunakan adalah angket yang disajikan dengan serangkaian alternatif jawaban. Angket sebagai alat pengumpul data berupa formulir yang harus diisi secara tertulis oleh sejumlah responden agar mendapatkan respon dan jawaban dari apa yang diharapkan. Angket diberikan kepada kepala sekolah, rekan sejawat dan siswa, serta guru fisika yang diobservasi. Angket berisi pertanyaan tentang aspek kompetensi pedagogik, profesional, kepribadian dan sosial. Setiap pertanyaan tentang aspek kompetensi guru diberikan rentang kategori yaitu: sangat kurang, kurang, cukup, baik, sangat baik.

Lembar observasi yang digunakan merupakan lembar pengamatan yang di dalamnya terdapat komponen dari indikator masing-masing kompetensi yang akan diukur. Dalam penelitian ini observasi dilakukan dalam rangka memperoleh informasi mengenai proses peembelajaran fisika di dalam kelas. Keterlaksanaan pembelajaran ini dikategorikan ke dalam kompetensi pedagogik guru fisika. Observasi merupakan sarana pengumpulan data yang dilakukan secara sistematis pada pengamatan keadaan secara wajar tanpa adanya manipulasi data.

Dalam kegiatan observasi tersebut yang menjadi sumber data adalah: (1) aktivitas pembelajaran Fisika di kelas dengan guru fisika sebagai subjek penelitian. Pengamatan yang dilakukan meliputi bagaimana guru menciptakan suasana belajar yang kondusif, guru memberikan pembelajaran yang sesuai dengan Kompetensi Dasar pembelajaran, sikap dan perilaku guru selama pembelajaran dan kemampuan guru dalam penguasaan konsep dasar. (2) Perangkat pembelajaran guru berupa dokumen administrasi pembelajaran: silabus, RPP, buku teks, Lembar Kerja Siswa dan media pembelajaran lain.

Lembar analisis dokumen berupa lembar penilaian perangkat pembelajaran guru fisika yang diisi oleh kepala sekolah. Dalam hal ini kepala sekolah selaku supervisor melakukan pemeriksaan terhadap dokumen perangkat pembelajaran yang sudah dibuat oleh guru fisika. Lembar tersebut dikelompokkan dalam tiga komponen perangkat pembelajaran, yaitu silabus, rencana pelaksanaan pembelajaran dan lembar kegiatan siswa. Dokumentasi bertujuan untuk mendapatkan bukti-bukti fisik mengenai data yang diperlukan.

Teknik analisis data yang digunakan dalam penelitian ini adalah analisis data kualitatif yang dikonversikan menjadi data kuantitatif. Analisis tersebut bertujuan untuk mendeskripsikan dan menggambarkan data yang terkumpul sebagaimana adanya dari masing-masing aspek kompetensi guru. Hasil analisis ini kemudian dibandingkan dengan acuan kriteria penilaian yang telah ditentukan berdasarkan rata-rata ideal (Mi), simpangan baku ideal (Sbi), skor tertinggi ideal, skor terendah ideal dan rentang kriteria/kategori yang dicapai oleh masing-masing instrumen dalam tiap kompetensi yang diukur oleh penilai/pengamat. Tabulasi data yang berupa jumlah skor dari tiap aspek kompetensi dikelompokkan berdasarkan komponen (kompetensi dan penilai/pengamat). Dengan menggunakan program Microsoft Excel, maka diperoleh nilai total skor, jumlah, rerata jumlah, rerata skor, kriteria masing-masing kompetensi guru berdasarkan aspek kompetensi dan penilai/pengamat. Setelah itu diperoleh histogram aspek kompetensi terhadap kriteria/kategori dan aspek kompetensi terhadap nilai rerata skor untuk setiap komponen penelitian berdasarkan kompetensi dan pengamat (responden). Hasil analisis pada penelitian ini berupa penyajian data dalam bentuk histogram yang merupakan interpretasi dari masing-masing kompetensi dan penilai, berdasarkan aspek kompetensi terhadap kategori/kriteria dan nilai rerata skor.

Dari data yang terkumpul pada penelitian selanjutnya dilakukan analisis dengan teknik analisis deskriptif kuantitatif yaitu mendeskripsikan dan memaknai tiap-tiap komponen yang kemudian dibandingkan dengan acuan kriteria berdasarkan Skor Rerata Ideal (Mi) dan Skor Simpangan Baku Ideal (Sbi) yang dicapai oleh instrumen. Untuk menentukan kriteria atau kategori skor tiap komponen digunakan acuan kriteria skala Likert yaitu Skala 5. Konversi skor menjadi kriteria dengan menggunakan angket atau kuesioner skala 5 (lima) disajikan pada Tabel 4.

Tabel 4. Konversi skor menjadi kriteria skala 5 
Jurnal Pendidikan Fisika dan Keilmuan (JPFK) Vol 3 No 2 September 2017, hal 96-109

Avaliable online at: http://e-journal.unipma.ac.id/index.php/JPFK

Print ISSN: 2442-8868, Online ISSN: 2442-904x

\begin{tabular}{ccc}
\hline No & Persamaan Rentang & Kriteria \\
\hline 1 & $\bar{x}>M i+1,8 \mathrm{Sbi}$ & Sangat \\
2 & $(M i+1,8 \mathrm{Sbi})<\bar{x} \leq(\mathrm{Mi}+0,6 \mathrm{Sbi})$ & Baik \\
3 & $(M i+0,6 \mathrm{Sbi})<\bar{x} \leq(\mathrm{Mi}-0,6 \mathrm{Sbi})$ & Cukup \\
4 & $(M i-0,6 \mathrm{Sbi})<\bar{x} \leq(M i-1,8 \mathrm{Sbi})$ & Kurang \\
5 & $\bar{x}<M i-1,8 \mathrm{Sbi}$ & Sangat \\
& & Kurang \\
\hline
\end{tabular}

(Widoyoko: 2009)

Untuk menentukan besarnya rerata ideal (Mi) dan simpangan baku ideal (Sbi), maka digunakan persamaan sebagai berikut:

$$
\begin{array}{lll}
n & = & \text { banyaknya butir pertanyaan setiap } \\
& \text { aspek } \\
i & = & \text { skor tiap butir pertanyaan } \\
\Sigma i & = & \text { jumlah skor butir pertanyaan setiap } \\
& & \text { aspek pada setiap individu guru } \\
\bar{x} & = & \text { rerata jumlah } \mathrm{n} \text { guru setiap aspek } \\
\mathrm{Sti} & = & \text { skor tertinggi ideal }=5 n \\
\mathrm{Sri} & = & \text { skor terendah ideal }=1 n \\
\mathrm{Mi} & = & \text { mean ideal }=\frac{1}{2}(\mathrm{Sti}+\mathrm{Sri}) \\
\mathrm{Sbi} & = & \text { simpangan baku ideal } \\
& =\frac{1}{6}(\text { Sti }- \text { Sri })
\end{array}
$$

\section{Hasil Penelitian dan Pembahasan}

Penelitian tersebut bertujuan untuk mendapatkan peta kompetensi pedagogik, profesional, kepribadian dan sosial guru fisika SMA yang sudah sertifikasi di Kabupaten

Tabel 5. Hasil penilaian kompetensi pedagogik guru fisika

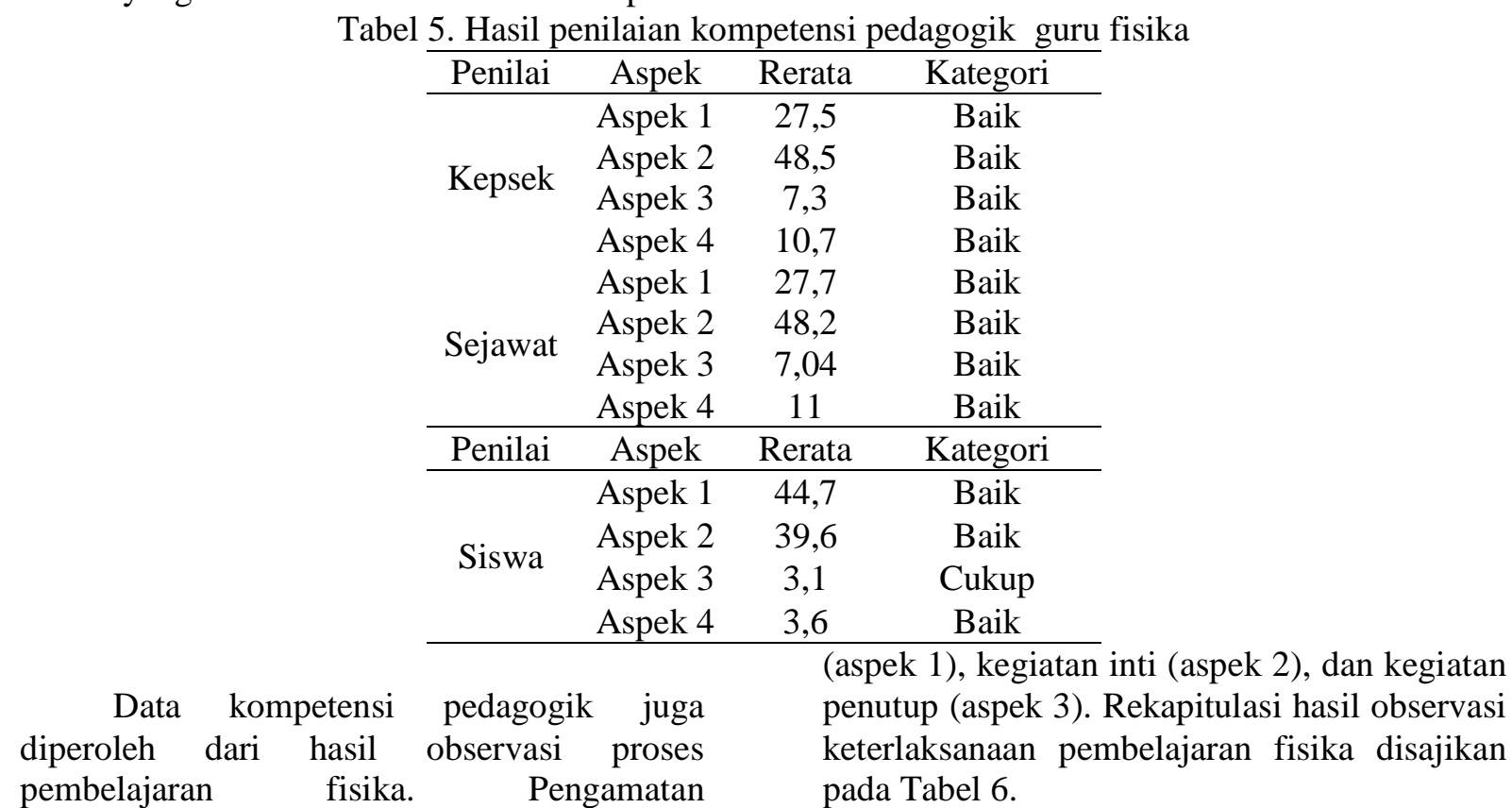

(aspek 1), kegiatan inti (aspek 2), dan kegiatan

Data kompetensi pedagogik juga diperoleh dari hasil observasi proses pembelajaran fisika. Pengamatan keterlaksanaan pembelajaran meliputi tiga

aspek, yaitu kegiatan pra pembelajaran

Tabel 6. Hasil observasi penilaian keterlaksanaan pembelajaran
Kulon Progo. Sumber data penelitian diperoleh dari beberapa responden, yaitu 23 orang guru fisika, 13 orang kepala sekolah, 13 orang rekan sejawat guru fisika, dan 115 orang siswa. Data penelitian mengenai kompetensi guru diperoleh melalui hasil angket, hasil observasi, hasil analisis dokumen dan portofolio atau biodata guru fisika. Data penelitian terdiri dari data kuantitatif dan data kualitatif.

Penilaian kompetensi pedagogik guru fisika meliputi empat aspek kompetensi, yaitu menguasai karakteristik peserta didik (aspek 1), melaksanakan kegiatan pembelajaran yang menarik dan mengembangkan potensi siswa (aspek 2), mengembangkan dan memanfaatkan media pembelajaran (aspek 3), dan melaksanakan evaluasi dan memanfaatkan hasil penilaian untuk kepentingan pembelajaran (aspek 4). Rekapitulasi hasil angket penilaian kompetensi pedagogik guru fisika disajikan pada Tabel 5.

Penilai Aspek Rerata Kategori


Jurnal Pendidikan Fisika dan Keilmuan (JPFK) Vol 3 No 2 September 2017, hal 96-109

Avaliable online at: http://e-journal.unipma.ac.id/index.php/JPFK

Print ISSN: 2442-8868, Online ISSN: 2442-904x

\begin{tabular}{cccc}
\hline \multirow{3}{*}{ Kepsek } & Aspek 1 & 16,3 & Baik \\
& Aspek 2 & 91 & Baik \\
& Aspek 3 & 11,8 & Baik \\
\hline
\end{tabular}

menguasai struktur serta metode keilmuan

Penilaian kompetensi profesional guru fisika meliputi dua aspek kompetensi, yaitu menguasai substansi keilmuan terkait dengan bidang studi yang diampu (aspek 1) dan (aspek 2). Rekapitulasi hasil angket penilaian kompetensi profesional guru fisika disajikan pada Tabel 7.

Tabel 7. Hasil penilaian kompetensi profesional guru fisika

\begin{tabular}{|c|c|c|c|c|}
\hline Penilai & Aspek & Rerata & Kategori & \\
\hline \multirow{2}{*}{ Kepsek } & Aspek 1 & 36 & Baik & \\
\hline & Aspek 2 & 15 & Kurang & \\
\hline \multirow[t]{2}{*}{ Sejawat } & Aspek 1 & 35,7 & Kurang & \\
\hline & Aspek 2 & 16,7 & Cukup & \\
\hline
\end{tabular}

dari hasil angket dan analisis dokumen. Penilaian dokumen pembelajaran meliputi tiga aspek, yaitu silabus (aspek 1), RPP (aspek 2),

Tabel 8. Hasil penilaian dokumen perangkat pembelajaran guru fisika

\begin{tabular}{cccc}
\hline Penilai & Aspek & Rerata & Kategori \\
\hline \multirow{3}{*}{ Kepsek } & Aspek 1 & 66,5 & Baik \\
& Aspek 2 & 82,2 & Baik \\
& Aspek 3 & 67,8 & Baik \\
\hline
\end{tabular}

Penilaian kompetensi kepribadian guru berwibawa, akhlak mulia serta dapat menjadi fisika meliputi tiga aspek, yaitu memiliki teladan (aspek 3), Rekapitulasi hasil angket kepribadian yang mantap, stabil dan dewasa penilaian kompetensi kepribadian guru fisika (aspek 1), memiliki etos kerja, tanggung jawab disajikan pada Tabel 9. dan rasa percaya diri (aspek 2), dan memiliki kepribadian yang arif dan bijaksana,

Tabel 9. Hasil penilaian kompetensi kepribadian guru fisika

\begin{tabular}{cccc}
\hline Penilai & Aspek & Rerata & Kategori \\
\hline \multirow{5}{*}{ Kepsek } & Aspek 1 & 38,7 & Sangat baik \\
& Aspek 2 & 38,7 & Sangat baik \\
& Aspek 3 & 31,7 & Sangat baik \\
& Aspek 1 & 21 & Sangat baik \\
Sejawat & Aspek 2 & 44 & Baik \\
& Aspek 3 & 37 & Baik \\
& Aspek 1 & 24,7 & Baik \\
Siswa & Aspek 2 & 15,8 & Baik \\
& Aspek 3 & 41,4 & Baik \\
\hline
\end{tabular}

beradaptasi dengan baik di satuan pendidikan

Penilaian kompetensi sosial guru fisika meliputi tiga aspek kompetensi, yaitu berkomunikasi dan bergaul secara efektif dan santun (aspek 1), bersikap inklusif, bertindak objektif dan tidak diskriminatif (aspek 2), dan tempat bertugas dan lingkungan masyarakat (aspek 3), Rekapitulasi hasil angket penilaian kompetensi sosial guru fisika disajikan pada Tabel 10.

Tabel 10. Hasil penilaian kompetensi sosial guru fisika

\begin{tabular}{cccc}
\hline Penilai & Aspek & Rerata & Kategori \\
\hline \multirow{3}{*}{ Kepsek } & Aspek 1 & 29 & Baik \\
& Aspek 2 & 37,2 & Baik \\
& Aspek 3 & 35,9 & Baik \\
Sejawat & Aspek 1 & 28,1 & Baik \\
\cline { 2 - 4 } & &
\end{tabular}




\begin{tabular}{lccc}
\hline & Aspek 2 & 35,8 & Baik \\
& Aspek 3 & 35 & Baik \\
\multirow{3}{*}{ Siswa } & Aspek 1 & 12,5 & Baik \\
& Aspek 2 & 47,9 & Baik \\
& Aspek 3 & 18,7 & Baik \\
\hline
\end{tabular}

Dari penjabaran di atas secara umum dapat disimpulkan bahwa guru fisika SMA di Kulon Progo telah menguasai kompetensi pedagogik, profesional, kepribadian dan sosial dengan baik. Hasil yang diperoleh dari pengamatan di lapangan menunjukkan kemampuan guru fisika yang relatif beragam dalam memahami karakteristik siswa. Guru menggunakan berbagai pendekatan dalam proses pembelajaran di kelas. Guru fisika telah mampu memberikan pengalamannya agar proses pembelajaran berjalan menarik sehingga dapat memotivasi dan mengoptimalkan potensi siswa.

Pemanfaatan media pembelajaran fisika berbasis teknologi informasi dan komputer sudah digunakan oleh beberapa guru dalam pembelajaran fisika. Pada prinsipnya penggunaan media pembelajaran tersebut bertujuan untuk menarik perhatian dan mempermudah pemahaman siswa dalam kaitannya dengan substansi kelimuan fisika.

Berdasarkan hasil pengamatan di lapangan, secara umum guru fisika SMA di Kulon progo sudah dapat menggunakan kemampuan personalnya untuk berkomunikasi dan bergaul secara efektif kepada siswa, sesama pendidik dan tenaga kependidikan, orangtua siswa, dan masyarakat yang berada di lingkungan sekolah. Beberapa guru juga aktif dalam organisasi, baik di dalam maupun di luar sekolah.

Data kualitatif berupa data portofolio guru fisika SMA di Kabupaten Kulon Progo. Data tersebut digunakan untuk memperoleh informasi dari guru fisika mengenai unit kerja, status akreditasi sekolah, status kepegawaian, pangkat, golongan, sertifikat pendidik, bidang studi yang diampu, masa kerja, kualifikasi pendidikan, beban mengajar, pendididikan dan pelatihan, penelitian, pengembangan media, pengalaman organisasi dari guru fisika yang bersangkutan, serta kegiatan pengembangan diri dan profesi.

Berdasarkan data portofolio secara spesifik akan ditinjau pada aspek pangkat/golongan, kualifikasi akademik, pengalaman mengajar, dan beban mengajar guru fisika, serta kegiatan yang pernah diikuti oleh guru fisika dalam rangka pengembangan diri dan profesi.

Pengalaman mengajar adalah masa kerja sebagai guru, kepala sekolah, atau pengawas satuan pendidikan pada jenjang pendidikan formal. Dalam hal ini pengalaman mengajar guru fisika dikelompokkan menjadi enam (6) jenjang masa kerja. Hasil portofolio guru fisika SMA di Kulon Progo ditinjau dari masa kerja ditunjukkan pada Gambar 1.

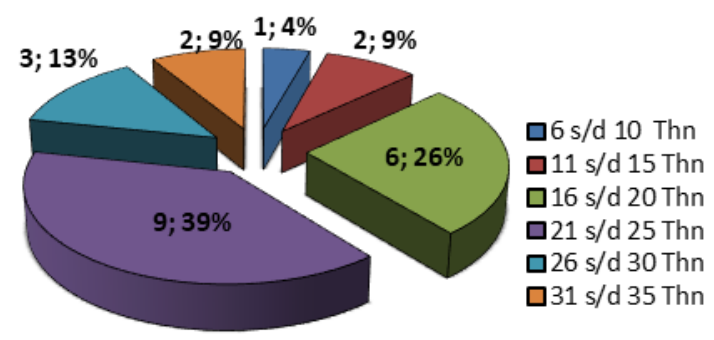

Gambar 1. Diagram persentase guru fisika berdasarkan pengalaman mengajar

Pada Gambar 1, menunjukkan bahwa $96 \%$ atau 22 orang guru fisika SMA di Kulon Progo telah memiliki pengalaman mengajar lebih dari 10 tahun. Terdapat satu (1) orang guru fisika yang memiliki pengalaman mengajar kurang dari 10 tahun.
Rekapitulasi data hasil rerata skor kompetensi pedagogik, profesional, kepribadian dan sosial guru fisika SMA di Kabupaten Kulon Progo berdasarkan data kelompok masa kerja disajikan pada Tabel 11. Masa kerja guru dibagi dalam enam kelompok (Kl), yaitu: Kelompok I: 6-10 tahun; 
Kelompok II: 11-15 tahun; Kelompok III: 1620 tahun; Kelompok IV: 21-25 tahun;
Kelompok V: 26-30 tahun; Kelompok VI: $>30$ tahun.

Tabel 11. hasil rerata skor tiap kompetensi berdasarkan kelompok masa kerja guru

\begin{tabular}{ccccccccc}
\hline Kl & $\begin{array}{c}\text { skor } \\
\text { ped }\end{array}$ & K & $\begin{array}{c}\text { skor } \\
\text { prof }\end{array}$ & K & $\begin{array}{c}\text { skor } \\
\text { kep }\end{array}$ & K & $\begin{array}{c}\text { skor } \\
\text { sos }\end{array}$ & K \\
\hline I & 110 & S & 56 & B & 102 & B & 101 & B \\
II & 91 & B & 47 & C & 113 & SB & 103 & B \\
III & 93 & B & 54 & B & 111 & SB & 106 & S \\
IV & 94 & B & 48 & C & 110 & SB & 101 & B \\
V & 95 & B & 49 & C & 98 & SB & 92 & B \\
VI & 88 & B & 55 & B & 106 & SB & 98 & B \\
\hline
\end{tabular}

Berdasarkan data pada Tabel 11, dapat diketahui bahwa guru fisika yang mempunyai masa kerja 6-10 tahun memiliki kompetensi dalam kategori, kompetensi pedagogik sangat baik, kompetensi profesional baik, kompetensi kepribadian baik, dan kompetensi sosial baik. Guru fisika dengan masa kerja 11-15 tahun memiliki kompetensi dalam kategori kompetensi pedagogik baik, kompetensi profesional cukup baik, kompetensi kepribadian sangat baik, dan kompetensi sosial baik. Guru fisika dengan masa kerja 16-20 tahun memiliki kompetensi pedagogik baik, kompetensi profesional baik, kompetensi kepribadian sangat baik, dan kompetensi sosial sangat baik. Kelompok guru fisika dengan masa kerja 21-25 tahun dan 26-30 tahun,

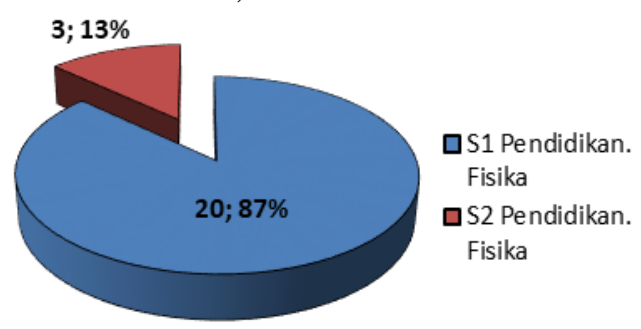

Gambar 2. Diagram persentase guru fisika berdasarkan kualifikasi akademik

Pada Gambar 2, menunjukkan bahwa $87 \%$ atau 20 orang guru fisika telah memiliki ijazah Sarjana S-1 pendidikan fisika dan 13\% atau 3 orang guru yang sudah berijazah S-2 pendidikan fisika. Hasil ini menunjukkan semua guru fisika telah memenuhi standar minimal kualifikasi akademik yang dipersyaratkan.

Tabel 12. hasil rerata skor tiap kompetensi berdasarkan kelompok kualifikasi guru

\begin{tabular}{ccccccccc}
\hline Kl & $\begin{array}{c}\text { skor } \\
\text { ped }\end{array}$ & K & $\begin{array}{c}\text { skor } \\
\text { prof }\end{array}$ & K & $\begin{array}{c}\text { skor } \\
\text { kep }\end{array}$ & K & $\begin{array}{c}\text { skor } \\
\text { sos }\end{array}$ & K \\
\hline I & 93 & B & 49 & C & 108 & SB & 101 & B \\
II & 101 & B & 60 & B & 116 & SB & 112 & SB \\
\hline
\end{tabular}
kepribadian dan sosial guru fisika berdasarkan Kelompok I: S1 Pendidikan Fisika; dan Kelompok II: S2 Pendidikan Fisika. memiliki kompetensi pedagogik baik, kompetensi profesional cukup baik, kompetensi kepribadian sangat baik, dan kompetensi sosial baik. Guru fisika dengan masa kerja lebih dari 30 tahun memiliki kompetensi pedagogik baik, kompetensi profesional baik, kompetensi kepribadian sangat baik, dan kompetensi sosial baik.

Kualifikasi akademik yang wajib dimiliki oleh seorang guru SMA/MA adalah pendidikan akademik (S-1, S-2, atau S-3) maupun Diploma IV (D-IV) baik di dalam maupun di luar negeri dari program studi yang terakreditasi. Hasil portofolio guru fisika SMA di Kulon Progo ditinjau dari kualifikasi akademik ditunjukkan pada Gambar 2.

Rekapitulasi data hasil rerata skor dari kompetensi pedagogik, profesional, data kelompok kualifikasi akademik disajikan pada Tabel 12. Kualifikasi akademik guru dibagi dalam dua kelompok, yaitu: 

Berdasarkan data pada Tabel 12, dapat diketahui bahwa kelompok guru fisika yang mempunyai kualifikasi akademik S1 pendidikan fisika, memiliki kompetensi pedagogik baik, kompetensi profesional cukup baik, kompetensi kepribadian sangat baik, dan kompetensi sosial baik. Guru fisika yang mempunyai kualifikasi akademik S2 pendidikan fisika memiliki kompetensi pedagogik baik, kompetensi profesional baik, kompetensi kepribadian sangat baik, dan kompetensi sosial sangat baik.

Seluruh guru fisika yang menjadi sampel dalam penelitian ini sudah memiliki sertifikat pendidik. Oleh karena itu seluruh guru fisika telah memenuhi persyaratan beban mengajar minimal 24 jam per minggu. Hasil portofolio guru fisika SMA di Kabupaten Kulon Progo ditinjau dari beban mengajar ditunjukkan pada Gambar 3.

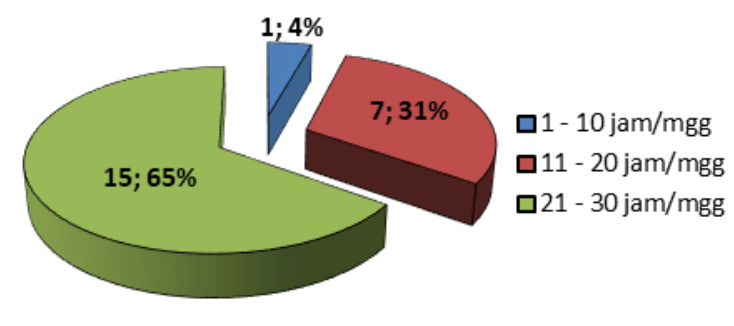

Gambar 3. Diagram persentase guru fisika berdasarkan beban mengajar

Rekapitulasi data hasil rerata skor dari

Pada Gambar 3, menunjukkan bahwa $96 \%$ atau 22 orang guru fisika memiliki beban mengajar diatas $21 \mathrm{jam} / \mathrm{ming} g u$ dan hanya terdapat satu (1) orang guru yang memiliki beban mengajar kurang dari 10 jam per minggu. Namun hal ini sudah diatasi dengan peenambahan beban mengajar guru yang bersangkutan di unit kerja atau satuan pendidikan lainnya ataupun dengan cara memberikan tugas tambahan kepada guru tersebut.

Tabel 13. hasil rerata skor tiap kompetensi berdasarkan kelompok kualifikasi guru

\begin{tabular}{ccccccccc}
\hline Kl & $\begin{array}{c}\text { skor } \\
\text { ped }\end{array}$ & K & $\begin{array}{c}\text { skor } \\
\text { prof }\end{array}$ & K & $\begin{array}{c}\text { skor } \\
\text { kep }\end{array}$ & K & $\begin{array}{c}\text { skor } \\
\text { sos }\end{array}$ & K \\
\hline I & 92 & B & 45 & C & 106 & SB & 93 & B \\
II & 92 & B & 52 & B & 106 & SB & 101 & B \\
III & 92 & B & 51 & B & 110 & SB & 103 & B \\
\hline
\end{tabular}

Berdasarkan data pada Tabel 13, dapat diketahui bahwa guru fisika yang mempunyai beban mengajar 1-10 jam/minggu, memiliki kompetensi pedagogik baik, kompetensi profesional cukup baik, kompetensi kepribadian sangat baik, dan kompetensi sosial baik. Kelompok guru fisika yang mempunyai beban mengajar 11-20 jam/minggu dan 21-30

jam/minggu memiliki kompetensi pedagogik baik. golongan ditunjukkan pada Gambar 4. kompetensi pedagogik, profesional, kepribadian dan sosial guru fisika berdasarkan data kelompok beban mengajar disajikan pada Tabel 13. Beban mengajar guru dibagi dalam tiga kelompok, yaitu sebagai berikut: Kelompok I: 1-10 jam/minggu; dan Kelompok II: 11-20 jam/minggu; dan Kelompok III: 21-30 jam/minggu. baik, kompetensi profesional baik, kompetensi kepribadian sangat baik, dan kompetensi sosial

Hasil portofolio guru fisika SMA di Kulon Progo ditinjau dari pangkat dan

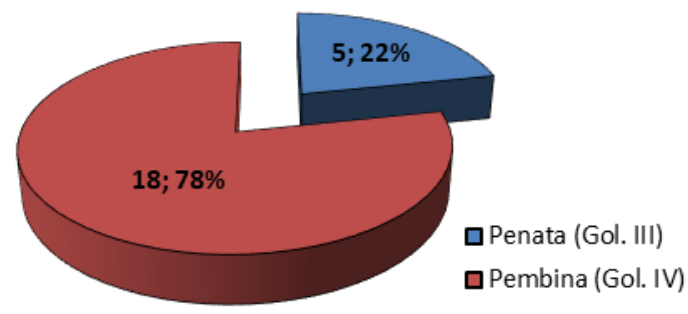


Gambar 4. Diagram persentase guru fisika berdasarkan pangkat dan golongan

Pada Gambar 4, menunjukkan bahwa $78 \%$ atau delapan belas (18) orang guru fisika sudah memiliki pangkat Pembina dengan ratarata golongan IVa dan $22 \%$ atau lima (5) orang guru yang memiliki pangkat Penata muda (III.b) dan Penata tingkat 1 (III.d).

Rekapitulasi data hasil rerata skor dari kompetensi pedagogik, profesional,

Tabel 14. hasil rerata skor tiap kompetensi berdasarkan kelompok kualifikasi guru

\begin{tabular}{ccccccccc}
\hline Kl & $\begin{array}{c}\text { skor } \\
\text { ped }\end{array}$ & K & $\begin{array}{c}\text { skor } \\
\text { prof }\end{array}$ & K & $\begin{array}{c}\text { skor } \\
\text { kep }\end{array}$ & K & $\begin{array}{c}\text { skor } \\
\text { sos }\end{array}$ & K \\
\hline I & 96 & B & 49 & C & 108 & SB & 102 & B \\
II & 94 & B & 51 & C & 109 & SB & 102 & B \\
\hline
\end{tabular}

Berdasarkan data pada Tabel 14, dapat diketahui bahwa guru fisika yang mempunyai pangkat/golongan Penata/III, memiliki kompetensi pedagogik dengan kategori baik, kompetensi profesional cukup baik, kompetensi kepribadian sangat baik, dan kompetensi sosial baik. Kelompok guru fisika yang mempunyai pangkat/golongan Pembina/IV memiliki kompetensi pedagogik dengan kategori baik, kompetensi profesional cukup baik, kompetensi kepribadian sangat baik, dan kompetensi sosial baik.

Berdasarkan uraian di atas dapat disimpulkan bahwa, secara garis besar guru fisika SMA di Kabupaten Kulon Progo telah memenuhi standar minimal kualifikasi akademik yang dipersyaratkan dan memiliki kompetensi pedagogik, profesional, kepribadian dan sosial yang baik.

\section{Simpulan dan Saran}

Simpulan

Berdasarkan analisis dan pembahasan dapat disimpulkan beberapa hal, diantaranya sebagai berikut: (1) Penguasaan kompetensi pedagogik guru fisika SMA di Kulon Progo yang sudah sertifikasi secara keseluruhan masuk dalam kategori baik. Dokumen perangkat pembelajaran yang dibuat oleh guru fisika masuk dalam kategori baik. (2) Masa kerja tidak berpengaruh positif terhadap kompetensi pedagogik. Tidak terdapat interaksi positif antara kualifikasi akademik dengan kompetensi pedagogik. Beban mengajar tidak berpengaruh positif terhadap kompetensi pedagogik. Tidak terdapat interaksi positif antara pangkat/golongan dengan kompetensi pedagogik. (3) Penguasaan kepribadian dan sosial guru fisika berdasarkan data kelompok pangkat/golongan disajikan pada Tabel 14. Pangkat atau golongan guru dibagi dalam dua kelompok, yaitu sebagai berikut: Kelompok I: Penata/III; dan Kelompok II: Pembina/IV.

kompetensi profesional guru fisika SMA di Kulon Progo yang sudah sertifikasi secara keseluruhan ditinjau pada aspek menguasai substansi keilmuan terkait dengan bidang studi yang diampu dalam kategori baik dan pada aspek menguasai struktur dan metode keilmuan dalam kategori cukup. Keterlaksanaan pembelajaran guru fisika secara keseluruhan masuk dalam kategori baik. (4) Masa kerja tidak berpengaruh positif terhadap kompetensi profesional. Terdapat interaksi positif antara kualifikasi akademik dengan kompetensi profesional. Beban mengajar berpengaruh positif terhadap kompetensi profesional. Tidak terdapat interaksi positif antara pangkat/golongan dengan kompetensi profesional. Penguasaan kompetensi kepribadian guru fisika SMA di Kulon Progo yang sudah sertifikasi secara keseluruhan masuk dalam kategori sangat baik. (6) Masa kerja berpengaruh terhadap kompetensi kepribadian. Kualifikasi akademik berpengaruh terhadap kompetensi kepribadian. Beban mengajar berpengaruh terhadap kompetensi kepribadian guru. Pangkat/golongan berpengaruh terhadap kompetensi kepribadian. (7) Penguasaan kompetensi sosial guru fisika SMA di Kulon Progo yang bersertifikat profesi secara keseluruhan masuk dalam kategori baik. (8) Masa kerja tidak berpengaruh terhadap kompetensi sosial. Kualifikasi akademik berpengaruh positif terhadap kompetensi sosial. Beban mengajar berpengaruh positif terhadap kompetensi sosial. Tidak terdapat interaksi positif antara pangkat/golongan dengan kompetensi sosial.

Saran

Perlu dilakukan penelitian lebih lanjut mengenai pemetaan kompetensi guru dengan 
objek dan lokasi penelitian yang berbeda serta menggunakan instrumen dan teknis pelaksanaan yang lebih terukur.

Rekomendasi implikatif yang diajukan adalah sebagai bahan evaluasi bagi para guru khususnya guru fisika SMA untuk meningkatkan seluruh kompetensi yang wajib dimiliki. Sebagai bahan masukan untuk mengkoreksi dan mengevaluasi kebijakan terkait dengan sertifikasi guru, UKG dan PKG.

\section{Daftar Pustaka}

Badan Akreditasi Provinsi Sekolah/Madrasah (BAP-S/M). (2012). Direktori sekolah madrasah provinsi daerah istimewa yogyakarta tahun 2005-2011. Yogyakarta: Disdikpora

Carin, A.A., \& Sund, R.B.(1989). Teaching modern science ( $3 r d$ ed). Ohio: A Bell $\&$ Howell Company.

Depdiknas. (2003). Peraturan pemerintah republik indonesia nomor 20 tahun 2003 tentang sistem pendidikan nasional. Jakarta: Depdiknas.

Depdiknas. (2005). Undang-undang republik indonesia nomor 14 tahun 2005 tentang guru dan dosen. Jakarta: Depdiknas.

LPMP DIY. (2012). Data hasil uji kompetensi guru tingkat SMA/MA/SMK di provinsi daerah istimewa yogyakarta tahun 2012. Yogyakarta: Lembaga Penjaminan Mutu Pendidikan.

Lynn, V. C., \& Nixon, J. E. (1985). Physical education: teacher education, guidliness for sport pedagogy. New York: Jhon Wiley \& Sons. Inc.

Mastiyah, I. (2004). Profil kompetensi guru pendidikan agama islam di kota bandung. $\quad$ Bandung: Puslitbang Pendidikan Agama dan Keagamaan Depag.

Mulyasa, E. (2013). Uji kompetensi dan penilaian kinerja guru. Bandung: PT. Remaja Rosdakarya.

OECD Programme for International Student Assessment (PISA). (2010). PISA 2009 results: executive summary$O E C D . T e r s e d i a: w w w . o e c d . o r g /$ pisa/pisa products/46619703.pdf. Diakses 30 juni 2014.

Payong, M.R. (2011). Sertifikasi profesi guru (konsep dasar, problematika dan implementasinya). Jakarta: PT. Indeks.

Uno, H.B. (2007). Profesi kependidikan: problema, solusi, dan reformasi pendidikan di indonesia. Jakarta: Bumi Aksara.

Wahab, R., \& Sukirman. (2011). Bahan pendidikan dan latihan profesi guru sertifikasi guru rayon 111 universitas negeri yogyakarta (modul sekolah dasar). Yogyakarta: Kemendiknas UNY.

Widoyoko, E.P. (2009). Evaluasi program pembelajaran: panduan praktis bagi pendidik dan calon pendidik. Yogyakarta: Pustaka Belajar. 